\title{
Rationale for Use of Dopamine Agonists in Parkinson's Disease: Review of Ergot Derivatives
}

\author{
Pierre J. Blanchet
}

\begin{abstract}
While dopamine agonists are still traditionally used as adjunct medications to improve performance and smooth out motor response complications in advanced levodopa-treated Parkinson's disease, they are increasingly used in monotherapy or early in combination with levodopa particularly in patients under 65 years of age. Long-term studies using bromocriptine showed efficacy in lowering the cumulative levodopa dose and reducing the early incidence of levodopa-related motor response complications. New dopamine agonists have recently shown efficacy as adjunct medications in short-term trials. While we now have more options to fit our individual patients' needs and tolerance, it is important to view the new agonists in the light of the results obtained with ergot derivatives. In this article, the rationale for use and efficacy profile of the ergolines are briefly reviewed.
\end{abstract}

R SUM : Indications de l'utilisation des agonistes dopaminergiques dans la maladie de Parkinson: les d riv s de l'ergot de seigle. Les agonistes dopaminergiques sont traditionnellement utilisés comme adjuvants dans le but d'améliorer la performance et réduire les fluctuations motrices observées chez les malades dopa-traités aux stades avancés de la maladie de Parkinson. Toutefois, ils sont de plus en plus prescrits précocément dans la maladie, en monothérapie ou en combinaison avec la L-DOPA, surtout chez les malades de moins de 65 ans. Les essais cliniques prolongés avec la bromocriptine ont bien montré son efficacité à réduire la dose cumulative de L-DOPA utilisée et à diminuer l'incidence précoce des complications motrices associées à la dopathérapie. De nouveaux agonistes non dérivés de l'ergot de seigle ont récemment démontré leur efficacité lors d'essais cliniques de courte durée, nous donnant davantage de choix pour maîtriser les signes et symptômes de la maladie et les problèmes d'intolérance précoce. Il apparaît opportun de revoir les indications du traitement agoniste et les effets des dérivés de l'ergot de seigle dans la maladie de Parkinson en attendant la publication d'études cliniques contrôlées comparant les nouveaux agonistes aux premiers mis sur le marché.

Can. J. Neurol. Sci. 1999; 26: Suppl. 2-S21-S26

The role and optimal timing of introduction of dopamine agonists in the symptomatic treatment of Parkinson's disease (PD) are still unsettled. Reevaluation of these issues is required in light of new experimental data published on crucial therapeutic issues revolving around the mechanisms of induction of motor response complications and cell death. In spite of suggestive animal evidence that levodopa may be harmful to compromised dopamine neurons in vivo, ${ }^{1-2}$ there is no direct proof yet that levodopa results in irreversible dysfunction of the basal ganglia and catecholaminergic cell death in humans. ${ }^{3}$ Nonetheless, strategies to reduce (adjunct agonist therapy) or even replace (agonist monotherapy de novo) levodopa early in the disease have been explored for many years in an attempt to reduce long-term adverse effects. The advantages of direct dopamine agonists in PD include the lack of competition with dietary amino acids for absorption and absence of necessary enzymatic metabolic steps, leading to more reliable and consistent effects, a long duration of efficacy, greater potency, potential alternative modes of delivery, a reduced incidence of early motor response complications and possible neuroprotective properties. The clinical efficacy of the ergot derivatives is briefly reviewed to provide useful information for comparing their effects with newer dopamine agonists.

\section{Pharmacological Properties}

Bromocriptine [2-bromo $\alpha$-ergocryptine], pergolide mesylate [(8ß)-8-[(methylthio)methyl]-6- propylergoline], lisuride hydrogen maleate (1,1 diethyl-3-(9,10-didehydro-6-methyl-8 $\alpha$ ergolinylurea) and cabergoline (1-[(6-allylergoline- $8 \beta$-yl) carbonyl]-1-[3-(dimethylamino) propyl]-3- ethylurea) are all synthetic derivatives of lysergic acid (ergot derivatives) that differ from the newer, nonergoline dopamine agonists ropinirole and pramipexole (see elsewhere in this issue) in terms of their affinity for dopaminergic and nondopaminergic receptors. Ergot

From the Faculty of Dentistry, Université de Montréal and CHUM/Campus St. Luc, Montréal (Québec), Canada

Reprint requests to: Pierre J. Blanchet, $\mathrm{MD}, \mathrm{PhD}$, Neurosciences Research Unit, Research Centre/Rm 401, CHUM/Campus St. Luc, 1058 St.-Denis Street, Montréal, Québec, Canada H2X 3J4 
derivatives have a differential effect on the five dopamine receptor subtypes that have been characterized in the brain. All dopamine agonists bind to the $\mathrm{D} 2$ receptor subtype, a member of the D2-like receptors family which also includes D3 and D4 subtypes, a common feature generally linked to antiparkinsonian efficacy (Table). Studies suggest that ergot derivatives also display variable activity at the D1 receptor subtype with weak antagonism for bromocriptine, ${ }^{4-6}$ partial antagonism/agonism for lisuride ${ }^{7}$ and limited activity if any for cabergoline. ${ }^{8}$ Pergolide is the only drug that displays mild agonist activity at the D1 receptor subtype, ${ }^{9-11}$ but this has been disputed recently. ${ }^{12}$ The net contribution of the D1 receptor to the antiparkinsonian efficacy of the ergot derivatives is uncertain. However, it is now clear that the D1 receptor is not a silent bystander and that its activation can enhance D2 receptor-mediated responses in rodent ${ }^{13-16}$ and primate $^{17,18}$ models of $\mathrm{PD}$, and may even provide effective motor relief by itself in parkinsonian primates ${ }^{19-21}$ and PD patients. ${ }^{22-24}$ Although ergoline compounds show no D2:D3 receptor subtype selectivity, they all have significant affinity for the D3 subtype but less so in the case of bromocriptine. ${ }^{12,25}$ Whether this confers a definite advantage in terms of efficacy or adverse effect profile is unknown at present. Both pergolide and lisuride are 10 times more potent than bromocriptine on a milligram per milligram basis. Ergoline compounds also vary in terms of biological halflife (Table) but with the exception of cabergoline, their efficacy half-life appears to be more similar and to justify a TID dosing regimen.

Ergot derivatives display some affinity as well for other monoaminergic receptors. While bromocriptine binds preferentially to noradrenergic $\alpha_{1}$ receptors, the other ergolines have more affinity for $\alpha_{2}$ receptors and also show affinity for serotonergic $5-\mathrm{HT}_{1}$ and $5-\mathrm{HT}_{2}$ receptors, especially lisuride which is also a serotonin agonist. ${ }^{11}$ The nonselectivity of ergolines for monoaminergic receptors likely contributes to their safety and adverse effect profile, although the most frequent side effects seen in parkinsonian patients, namely nausea, dizziness, hypotension, dyskinesia, somnolence and hallucinations, are probably due to peripheral and central dopaminergic stimulation. All ergot drugs also presumably differ from the newer dopamine agonists in their incidence of adverse reactions such as erythromelalgia ${ }^{26}$ and fibrosis. ${ }^{27}$ The prevalence of symptomatic pleuropulmonary fibrosis during chronic bromocriptine treatment has been estimated to be as high as $2-5 \%$ over 5 years. ${ }^{27}$ Such complications appear infrequent with the other ergot derivatives and may affect less than 1 in 1,000 individuals treated with pergolide (Eli Lilly, data on file). These potentially serious complications are therefore uncommon within the recommended dose range and are largely reversible in most but perhaps not all cases upon drug withdrawal or reduction in dosage.

\section{DOPAMINE AGONISTS VERSUS LEVODOPA IN ANIMAL MODELS}

In 1-methyl-4-phenyl-1,2,3,6-tetrahydropyridine (MPTP)lesioned monkeys with moderately severe parkinsonism, bromocriptine provides an antiparkinsonian response of equal magnitude and longer duration compared with levodopa. ${ }^{28}$ In these animals, the absence of severe dose-limiting adverse reactions allows a substantial oral dose (up to $5 \mathrm{mg} / \mathrm{kg}$ ) to be administered. This proof of principle demonstration of the symptomatic efficacy of bromocriptine suggests that its apparent lower clinical efficacy compared with levodopa is related to low potency and an unfavorable therapeutic index. The MPTP-lesioned monkey has also allowed the dissection of the contribution of various dopamine receptor subtypes and nondopaminergic pathophysiological mechanisms responsible for levodopa-related motor response complications. Although the induction mechanisms responsible for such complications remain elusive, presynaptic and postsynaptic dopaminergic mechanisms are thought to contribute. ${ }^{29}$ Postsynaptic dopaminergic changes probably play a greater role than heretofore believed and are potentially reversible since motor response complications were ameliorated by the continuous delivery of levodopa for up to 12 days in PD patients but only gradually returned to baseline once oral levodopa treatment was resumed; ${ }^{30}$ continuous infusion for 3 months of the postsynaptic dopamine D2 receptor agonist lisuride was even more efficacious at increasing the antiparkinsonian benefit and therapeutic window (difference between threshold doses for clinical efficacy and side effects) of levodopa. ${ }^{31}$ Animal studies have shown that levodopa accentuates striatal changes in neuropeptide content, ${ }^{32}$ glutamic acid decarboxylase activity ${ }^{33}$ and mRNA expression, ${ }^{34}$ preproenkephalin mRNA ${ }^{35}$ expression, $\Delta$ FosB-like protein(s) expression, ${ }^{36}$ as well as pallidal changes in $\mathrm{GABA}_{\mathrm{A}}$ receptors ${ }^{37}$ brought about by chronic nigrostriatal denervation. Thus, standard short-acting levodopa is not physiological and further compromises the physiology of dopamine-denervated basal ganglia circuits.

Levodopa priming can set the stage for dopamine agonists to produce dyskinesia, even early on, contrasting with the response profile observed with agonist monotherapy in PD (see below). Under primed conditions, pharmacological studies in dopaminedenervated animals have suggested a dominance of dopamine D2 receptor-mediated mechanisms with enhanced responsiveness to a D2 agonist in rats ${ }^{38}$ and better reproducibility of levodopainduced dyskinesia following acute challenge with D2 agonists in

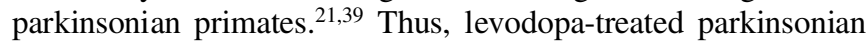
monkeys display a full antiparkinsonian response with dyskinesias following acute challenge with bromocriptine $(5 \mathrm{mg} / \mathrm{kg}$ orally), ${ }^{21}$ whereas levodopa-naive animals remain free of dyskinesia after weeks of bromocriptine treatment. ${ }^{28}$ The behavioral effect observed with bromocriptine as the first-line drug is similar to that

Table. Comparative pharmacological properties of ergot derivatives.

\begin{tabular}{lllllll}
\hline Agent & $\begin{array}{l}\text { Half-life } \\
(\mathbf{h r s})\end{array}$ & $\begin{array}{l}\text { Daily dose } \\
(\mathbf{m g})\end{array}$ & Dosing regimen & $\begin{array}{l}\text { Dopamine } \\
\text { receptor selectivity }\end{array}$ & $\begin{array}{l}\text { Norepinephrine } \\
\text { oreceptors }\end{array}$ & $\begin{array}{l}\text { Serotonergic } \\
\text { receptors }\end{array}$ \\
\hline Bromocriptine & 6 & $10-40$ & TID & D2 (D1-) & + & + \\
Pergolide & 27 & $1-4$ & TID & D2,D3 D 1 & + & + \\
Lisuride & $2-4$ & $1-5$ & TID & D2,D3 (D1-) & \pm & + \\
Cabergoline & 65 & $0.5-5$ & ID & D2 & \pm & \pm \\
\hline
\end{tabular}


obtained with a nonergoline selective D2 agonist administered continuously through a pump that also showed low dyskinesigenic potential. This response correlated in both cases with downregulation of putaminal $\mathrm{D} 2$ receptors ${ }^{37,40}$ and, in the case of the continuous nonergoline drug treatment, no further increase in pallidal GABA receptors compared with levodopa. ${ }^{37}$ In drug-naive MPTP-lesioned parkinsonian monkeys treated with cabergoline, dyskinesias were less frequent, less severe and more transient compared with levodopa-treated animals. ${ }^{41}$ This behavioral response also correlated with significant downregulation in putaminal D2 receptors. Thus, the low dyskinesigenic potential of bromocriptine and cabergoline may, at least in part, be related to longer duration of response compared with levodopa. Intuitively, long-acting pergolide would also be expected to provide similar results but this remains to be demonstrated. This response profile differs from that resulting from nonergoline short-acting dopamine D2 agonists that all showed great dyskinesigenic potential when chronically administered to drug-naive parkinsonian monkeys. ${ }^{42}$ This suggests that when adequately stimulated in a context of chronic dopamine denervation, the D2 receptor subtype can modulate motor function without long-term complications.

The same conclusions apply to the selective pharmacological stimulation of D1 receptors. Levodopa-treated parkinsonian primates showed dyskinesia but of lesser severity when acutely challenged with selective D1 agonists compared with the precursor levodopa. ${ }^{21}$ This is similar to PD patients administered infusions of the novel dopamine D1 receptor pro-agonist ABT-431.23 These observations are unlikely to result from changes in dopamine D1 receptor striatal binding since postmortem and positron emission tomography studies have failed to document consistent differences between dyskinetic and nondyskinetic cases. However, repeated administration of a short-acting D1 agonist to drug-naive parkinsonian monkeys rapidly produced a wearing-off effect and dyskinesia, ${ }^{43}$ while the same agonist administered continuously through a pump resulted in early and profound tachyphylaxis. ${ }^{44}$ Thus, it is highly unlikely that motor response complications result from abnormal regulation and sensitization of a single dopamine receptor subtype in the basal ganglia. The mode of dopamine receptor occupancy is likely of greater importance.

\section{Monotherapy in early Parkinson's disease}

Levodopa eventually leads to a short, fluctuating response associated with various dyskinesias in a substantial proportion of patients, particularly in young ${ }^{45}$ and more parkinsonian ${ }^{46,47}$ individuals. Although one recent study comparing immediate- and continuous-release levodopa preparations reported an unusually low incidence of motor fluctuations and dyskinesias of $20 \%$ over a 5 -year period, ${ }^{48}$ such complications can still arise rapidly in otherwise stable parkinsonian conditions ${ }^{46,49-51}$ and are therefore felt to be directly related to chronic levodopa oral intake.

Dopamine agonists (bromocriptine and lisuride in most studies) used in monotherapy in mild PD patients produce definite antiparkinsonian efficacy and seldom produce motor response complications. ${ }^{52-57}$ The improvement of motor disability resulting from bromocriptine may be greater than $50 \%$ in some patients and similar ${ }^{58,59}$ or only slightly inferior ${ }^{60}$ to levodopa in early PD. The magnitude of the response is dose-related and has been as high as $76 \%$ in patients administered daily doses of bromocriptine over $100 \mathrm{mg},{ }^{61}$ far exceeding the generally recommended and tolerated dose range for this drug. In levodopatreated patients showing good tolerance, single optimal doses of pergolide $^{62}$ and lisuride ${ }^{63}$ have compared advantageously with levodopa in terms of acute antiparkinsonian efficacy. In another study comparing cabergoline and levodopa, patients able to remain on monotherapy were improved to the same extent in both groups and, similar to lisuride, $62 \%$ of patients administered cabergoline did not require levodopa during the first year of treatment. ${ }^{64}$ Only a few patients developed dyskinesia in each group. In long-term studies, one in six patients could be managed satisfactorily with bromocriptine monotherapy for 5 years ${ }^{53,57}$ and about one in ten patients were satisfactorily treated with lisuride monotherapy for over 5 years ${ }^{65}$ with few adverse motor response complications. Bromocriptine monotherapy combined later with levodopa significantly delayed the emergence (4.9 vs. 2.7 years from first treatment; $p<0.01)$ and incidence $(14 / 25$ patients vs. $26 / 29$ patients; $p<0.01$ ) of motor response complications in PD patients compared with patients administered levodopa alone. ${ }^{21}$ This therapeutic strategy did not appear to put individuals at undue risk of developing early dyskinesias, which became manifest after a similar average latency once levodopa is added. ${ }^{55}$ The initiation of levodopa in far more advanced and severe patients may accelerate dyskinesias as the experience of MPTP-intoxicated subjects with severe parkinsonism suggests. ${ }^{46}$ Unfortunately, the dropout rate for bromocriptine and lisuride at one year averages $40-50 \%$ due to low tolerance or lack of efficacy, while it is approximately $27 \%$ for pergolide ${ }^{66}$ and only $7 \%$ in one study for cabergoline. ${ }^{67}$

A similar rationale underlies the early ("primary") combination of a dopamine agonist with levodopa. Most studies have used bromocriptine. Advocates of this strategy have argued that it reduces long-term motor response complications ${ }^{68-70}$ and mortality, ${ }^{71}$ while others have disagreed and criticized the methodologic flaws of previous studies. ${ }^{72}$ Nonetheless, early co-treatment with dopamine agonists can significantly lower the daily dose of levodopa administered (by $40 \%$ in one study with bromocriptine).$^{70}$ Chronic low-dose levodopa may delay the incidence of motor response complications, at least for several years, compared with high doses. ${ }^{73,74}$ Given the benefit provided by dopamine agonist monotherapy in early PD, even beyond the first year of treatment in a fraction of patients (see above), "primary" combination therapy (within 3 months) cannot be recommended as a general strategy and should be utilized only in those with a low tolerance for dopamine agonists despite gradual titration and the use of domperidone.

\section{Adjunct therapy in advanced Parkinson's disease}

The traditional indication for dopamine agonist use is to overcome motor response complications in advanced PD patients as adjunct therapy. These drugs are useful in the majority of patients but results have varied as greatly as the daily dose administered. When added to levodopa, ergot derivatives generally reduce total daily "off" time enough to allow a reduction in levodopa dosage by approximately $30 \%$. Co-treatment with bromocriptine has reduced levodopa dosage by $10 \%{ }^{75}$ to $71 \% .^{76}$ In a review of 9 studies, ${ }^{77}$ bromocriptine adjunct therapy improved "on" time in $71 \%$ of patients. Long-term results are 
usually less impressive. Similar results were obtained with pergolide with total daily dose of levodopa and total "off" time usually reduced by $25-40 \% .66,78,79$ The impact on dyskinesia is variable as persistence, emergence or increase in dyskinesia is reported. In general, an increase in dyskinesia produced by adjunct dopamine agonist therapy can be managed by a reduction in levodopa dosage without significant increase in motor disability. In one long-term study, dyskinesia significantly decreased after 3 years of pergolide treatment in spite of stable levodopa daily dosage. ${ }^{80}$ Ergot derivatives may also be beneficial for "off" period leg dystonia. In selected patients with advanced PD and severe levodopa-induced dyskinesia, highdose pergolide almost completely replaced levodopa intake and substantially reduced dyskinesia with reasonable control of PD symptoms. ${ }^{81}$ It is also worth noting that patients no longer responding to bromocriptine may still benefit from a trial of pergolide. ${ }^{82,83}$ Other limited and indirect evidence gathered in small patient populations also suggested that pergolide is clinically more effective in decreasing total "off" time than bromocriptine. ${ }^{84}$ Comparative studies between the new nonergoline agonists and pergolide are lacking.

Similar clinical results have been reported with lisuride (available in Europe) which reduced total “off" time by 70-130\% and daily levodopa intake by $20-50 \%$ following daily doses up to $5 \mathrm{mg}^{7}$ All parkinsonian features were improved, with some authors arguing that tremor was particularly responsive. Lisuride was also superior to bromocriptine in some studies. ${ }^{84}$ In 17 patients with motor response complications, the improvement in disability resulting from pergolide and lisuride use was similar but the impact on total "off" time was more significant with pergolide. ${ }^{84}$ The effect on dyskinesia was variable. Like levodopatreated parkinsonian monkeys challenged with selective dopamine D2 agonists, ${ }^{21}$ levodopa-treated PD patients exhibited peak dose dyskinesia following the acute intravenous administration of lisuride. ${ }^{85}$ Given the duration of clinical efficacy and thrice daily dosing regimen of most ergot derivatives (Table), the development of a practical means to deliver agonist therapy continuously would be advantageous. This strategy has been pursued with long-acting cabergoline which reduces total "off" time and disability and allows a reduction in levodopa dosage. ${ }^{67,86}$ This drug is currently not available for clinical use in PD in Canada.

\section{THE ISSUE OF NEUROPROTECTION}

Some experimental in vivo studies suggest that ergot derivatives may be neuroprotective. Indeed, chronic treatment with pergolide prevented the age-related attrition of midbrain dopamine neurons in rats ${ }^{87}$ while in mice, oral bromocriptine prevented the striatal dopamine loss produced by diethyldithiocarbamate and $\mathrm{MPTP}^{88}$ and intracerebroventricular bromocriptine protected mice against 6-hydroxydopamine-induced cell death. ${ }^{89}$ The mechanisms of action are not fully elucidated but direct free radical scavenging effect and stimulation of dopamine autoreceptors (reducing dopamine turnover and possibly the formation of neurotoxic radicals) may be involved. Some inconclusive preliminary studies suggest that lisuride and pergolide may be neuroprotective in PD. ${ }^{65,83,90,91}$ While there is no direct proof of levodopa neurotoxicity, ${ }^{3}$ all dopamine agonists also allow a nonspecific reduction in cumulative levodopa dose, thereby reducing the lifetime exposure to possibly neurotoxic free radi- cals. These hypotheses are certainly worth pursuing in prospective clinical trials.

\section{ACKNOWLEDGEMENTS}

The author wishes to acknowledge past support from the Fonds de la Recherche en Santé du Québec (FRSQ), The Parkinson Foundation of Canada and the National Institute of Neurological Disorders and Stroke.

\section{REFERENCES}

1. Blunt SB, Jenner P, Marsden CD. Suppressive effect of L-Dopa on dopamine cells remaining in the ventral tegmental area of rats previously exposed to the neurotoxin 6-hydroxydopamine. Mov Disord 1993; 8: 129-133.

2. Fukuda T, Watabe K, Tanaka J. Effects of bromocriptine and/or LDOPA on neurons in substantia nigra of MPTP-treated C57BL/6 mice. Brain Res 1996; 728: 274-276.

3. Agid Y. Levodopa - Is toxicity a myth? Neurology 1998; 50: 858863.

4. Trabucchi M, Spano PF, Tonon GC, Frattola L. Effects of bromocriptine on central dopaminergic receptors. Life Sci 1976; 19: 225-232.

5. Markstein R, Herrling PL, Bürki HR, Asper H, Ruch W. The effect of bromocriptine on rat striatal adenylate cyclase and rat brain monoamine metabolism. J Neurochem 1978; 31: 1163-1172.

6. Quik M, Iversen LL. Subsensitivity of the rat striatal dopaminergic system after treatment with bromocriptine: effects on $\left[{ }^{3} \mathrm{H}\right]$ spiperone binding and dopamine-stimulated cyclic AMP formation. Naunyn-Schmied Arch Pharmacol 1978; 304: 141-145.

7. Gopinathan G, Horowski R, Suchy IH. Lisuride pharmacology and treatment of Parkinson's disease. In: Calne DB, ed. Drugs for the Treatment of Parkinson's Disease. Berlin Heidelberg: SpringerVerlag, 1989; chap 19, 471-513.

8. Fariello RG, Carfagna N, Buonamici M, Dubini A. Cabergoline: a long-acting $\mathrm{D}_{2}$ agonist with antiparkinsonian properties - preclinical studies. Ann Neurol 1991: 30: 258.

9. Goldstein M, Lieberman A, Lew JY, et al. Interaction of pergolide with central dopaminergic receptors. Proc Natl Acad Sci USA 1980; 77: 3725-3728.

10. Andersen PH, Jansen JA. Dopamine receptor agonists: selectivity and dopamine D1 receptor efficacy. Eur J Pharmacol - Molec Pharmacol Sect 1990; 188: 335-347.

11. Wachtel H. Antiparkinsonian dopamine agonists: a review of the pharmacokinetics and neuropharmacology in animals and humans. J Neural Transm [P-D Sect] 1991; 3: 151-201.

12. De Keyser J, De Backer J-P, Wilczak N, Herroelen L. Dopamine agonists used in the treatment of Parkinson's disease and their selectivity for the $\mathrm{D}_{1}, \mathrm{D}_{2}$, and $\mathrm{D}_{3}$ dopamine receptors in human striatum. Prog Neuro-Psychopharmacol \& Biol Psychiat 1995; 19: 1147-1154.

13. Gershanik O, Heikkila RE, Duvoisin RC. Behavioral correlations of dopamine receptor activation. Neurology 1983; 33: 1489-1492.

14. Carlson JH, Bergstrom DA, Walters JR. Stimulation of both $D_{1}$ and D2 dopamine receptors appears necessary for full expression of postsynaptic effects of dopamine agonists: a neurophysiological study. Brain Res 1987; 400: 205-218.

15. Rouillard C, Bédard PJ. Specific $\mathrm{D}_{1}$ and $\mathrm{D}_{2}$ dopamine agonists have synergistic effects in the 6-hydroxydopamine circling model in the rat. Neuropharmacology 1988; 27: 1257-1264.

16. Robertson HA. Synergistic interactions of D1- and D2-selective dopamine agonists in animal models for Parkinson's disease: sites of action and implications for the pathogenesis of dyskinesias. Can J Neurol Sci 1992; 19: 147-152.

17. Gomez-Mancilla B, Boucher R, Gagnon C, et al. Effect of adding the D1 agonist CY 208-243 to chronic bromocriptine treatment. I: Evaluation of motor parameters in relation to striatal catecholamine content and dopamine receptors. Mov Disord 1993; 8: 144-150. 
18. Vermeulen RJ, Drukarch B, Sahadat MCR, et al. The dopamine D1 agonist SKF 81297 and the dopamine D2 agonist LY 171555 act synergistically to stimulate motor behavior of 1-methyl-4phenyl-1,2,3,6-tetrahydropyridine-lesioned parkinsonian rhesus monkeys. Mov Disord 1994; 9: 664-672.

19. Temlett JA, Chong PN, Oertel WH, Jenner P, Marsden CD. The D1 dopamine receptor partial agonist, CY 208-243, exhibits antiparkinsonian activity in the MPTP-treated marmoset. Eur J Pharmacol 1988; 156: 197-206.

20. Taylor JR, Lawrence MS, Redmond DE Jr, et al. Dihydrexidine, a full dopamine D1 agonist, reduces MPTP-induced parkinsonism in monkeys. Eur J Pharmacol 1991; 199: 389-391.

21. Blanchet P, Bédard PJ, Britton DR, Kebabian JW. Differential effect of selective D-1 and D-2 dopamine receptor agonists on levodopa-induced dyskinesia in 1-methyl-4-phenyl-1,2,3,6tetrahydropyridine-exposed monkeys. J Pharmacol Exp Therap 1993; 267: 275-279.

22. Temlett JA, Quinn NP, Jenner PG, et al. Antiparkinsonian activity of CY 208-243, a partial D-1 dopamine receptor agonist, in MPTP-treated marmosets and patients with Parkinson's disease. Mov Disord 1989; 4: 261-265.

23. Rascol O, Blin O, Descombes S, et al. ABT-431, a selective D1 agonist has efficacy in patients with Parkinson's disease. Neurology 1997; 48: A269-A270.

24. Blanchet PJ, Fang J, Gillespie M, et al. Effects of the full dopamine D1 receptor agonist dihydrexidine in Parkinson's disease. Clin Neuropharmacol (in press).

25. Sautel F, Griffon N, Lévesque D, et al. A functional test identifies dopamine agonists selective for D3 versus D2 receptors. NeuroReport 1995; 6: 329-332.

26. Eisler T, Hall RP, Kalavar KAR, Calne DB. Erythromelalgia-like eruption in parkinsonian patients treated with bromocriptine. Neurology 1981; 31: 1368-1370.

27. McElvaney NG, Wilcox PG, Churg A, Fleetham JA. Pleuropulmonary disease during bromocriptine treatment of Parkinson's disease. Arch Intern Med 1988; 148: 2231-2236.

28. Bédard PJ, Di Paolo T, Falardeau P, Boucher R. Chronic treatment with L-DOPA, but not bromocriptine induces dyskinesia in MPTP-parkinsonian monkeys. Correlation with $\left[{ }^{3} \mathrm{H}\right]$ spiperone binding. Brain Res 1986; 379: 294-299.

29. Chase TN, Engber TM, Mouradian MM. Contribution of dopaminergic and glutamatergic mechanisms to the pathogenesis of motor response complications in Parkinson's disease. In: Battistin L, Scarlato G, Caraceni T, Ruggieri S, eds. Advances in Neurology, vol 69: Drugs for the Treatment of Parkinson's Disease. Philadelphia: Lippincott-Raven, 1996: 62, 497-501.

30. Mouradian MM, Heuser IJE, Baronti F, Chase TN. Modification of central dopaminergic mechanisms by continuous levodopa therapy for advanced Parkinson's disease. Ann Neurol 1990; 27: 1823.

31. Baronti F, Mouradian MM, Davis TL, et al. Continuous lisuride effects on central dopaminergic mechanisms in Parkinson's disease. Ann Neurol 1992; 32: 776-781.

32. Engber TM, Susel Z, Kuo S, Gerfen CR, Chase TN. Levodopa replacement therapy alters enzyme activities in striatum and neuropeptide content in striatal output regions of 6-hydroxydopamine lesioned rats. Brain Res 1991; 552: 113-118.

33. Juncos JL, Engber TM, Raisman R, et al. Continuous and intermittent levodopa differentially affect basal ganglia function. Ann Neurol 1989; 25: 473-478.

34. Soghomonian J-J, Pedneault S, Blanchet PJ, et al. L-DOPA regulates glutamate decarboxylases mRNA levels in MPTP-treated monkeys. Mol Brain Res 1996; 39: 237-240.

35. Morissette M, Goulet M, Soghomonian J-J, et al. Preproenkephalin mRNA expression in the caudate-putamen of MPTP monkeys after chronic treatment with the D2 agonist U91356A in continuous or intermittent mode of administration: comparison with LDOPA therapy. Mol Brain Res 1997; 49: 55-62.

36. Doucet J-P, Nakabeppu Y, Bédard PJ, et al. Chronic alterations in dopaminergic neurotransmission produce a persistent elevation of FosB-like protein(s) in both rodent and primate striatum. Eur J Neurosci 1996; 8: 365-381.
37. Calon F, Goulet M, Blanchet PJ, et al. Levodopa or D2 agonist induced dyskinesia in MPTP monkeys: correlation with changes in dopamine and $\mathrm{GABA}_{\mathrm{A}}$ receptors in the striatopallidal complex. Brain Res 1995; 680: 43-52.

38. Engber TM, Susel Z, Juncos JL, Chase TN. Continuous and intermittent levodopa differentially affect rotation induced by D-1 and D-2 dopamine agonists. Eur J Pharmacol 1989; 168: 291-298.

39. Blanchet PJ, Gomez-Mancilla B, Bédard PJ. DOPA-induced "peak dose" dyskinesia: clues implicating D2 receptor-mediated mechanisms using dopaminergic agonists in MPTP monkeys. J Neural Transm 1995; 45(Suppl): 103-112.

40. Gagnon C, Bédard PJ, Di Paolo T. Effect of chronic treatment of MPTP monkeys with dopamine D-1 and/or D-2 receptor agonists. Eur J Pharmacol 1990; 178: 115-120.

41. Grondin R, Bédard PJ. Cabergoline: a promising agent for the treatment of Parkinson's disease. CNS Drug Rev 1996; 2: 214-225.

42. Bédard PJ, Gomez-Mancilla B, Blanchet P, et al. Role of selective D-1 and D-2 agonists in inducing dyskinesia in drug-naive MPTP monkeys. In: Narabayashi H, Nagatsu T, Yanagisawa N, Mizuno Y, eds. Advances in Neurology, Vol 60: From Basic Research to Treatment. New York: Raven Press, 1993, chap 16, 113-118.

43. Blanchet PJ, Grondin R, Bédard PJ. Dyskinesia and wearing-off following dopamine D1 agonist treatment in drug-naive 1-methyl-4phenyl-1, 2, 3, 6-tetrahydropyridine-lesioned primates. Mov Disord 1996; 11: 91-94.

44. Goulet M, Grondin R, Blanchet PJ, Bédard PJ, Di Paolo T. Dyskinesias and tolerance induced by chronic treatment with a D1 agonist administered in pulsatile or continuous mode do not correlate with changes of putaminal D1 receptors in drug-naive MPTP monkeys. Brain Res 1996; 719: 129-137.

45. Quinn N, Critchley P, Marsden CD. Young onset Parkinson's disease. Mov Disord 1987; 2: 73-91.

46. Langston JW, Ballard P. Parkinsonism induced by 1-methyl-4phenyl-1,2,3,6-tetrahydropyridine (MPTP): implications for treatment and the pathogenesis of Parkinson's disease. Can J Neurol Sci 1984; 11(Suppl): 160-165.

47. Bergmann KJ, Mendoza MR, Yahr MD. Parkinson's disease and long-term levodopa therapy. In: Yahr MD, Bergman KJ, eds. Advances in Neurology, Vol 45: Parkinson's Disease. New York: Raven Press, 1986, 463-467.

48. Block G, Liss C, Reines S, et al. Comparison of immediate-release and controlled release carbidopa/levodopa in Parkinson's disease. A multicenter 5-year study. Eur Neurol 1997; 37: 23-27.

49. Clarke CE, Boyce S, Sambrook MA, Crossman AR. Timing of levodopa therapy: evidence from MPTP-treated primates. Lancet 1987; $1: 625$.

50. Schneider JS. Levodopa-induced dyskinesias in parkinsonian monkeys: relationship to extent of nigrostriatal damage. Pharmacol Biochem Behav 1989; 34: 193-196.

51. Blanchet PJ, Allard P, Grégoire L, Tardif F, Bédard PJ. Risk factors for peak dose dyskinesia in 100 levodopa-treated parkinsonian patients. Can J Neurol Sci 1996; 23: 189-193.

52. Rascol A, Guiraud B, Montastruc JL, David J, Clanet M. Long-term treatment of Parkinson's disease with bromocriptine. J Neurol Neurosurg Psychiatry 1979; 42: 143-150.

53. Lees AJ, Stern GM. Sustained bromocriptine therapy in previously untreated patients with Parkinson's disease. J Neurol Neurosurg Psychiatry 1981; 44: 1020-1023.

54. Bergamasco B, Benna P, Scarzella L. Long-term bromocriptine treatment of de novo patients with Parkinson's disease. A sevenyear follow-up. Acta Neurol Scand 1990; 81: 383-387.

55. Montastruc JL, Rascol O, Senard JM, Rascol A. A randomized controlled study comparing bromocriptine to which levodopa was later added, with levodopa alone in previously untreated patients with Parkinson's disease: a five year follow up. J Neurol Neurosurg Psychiatry 1994; 57: 1034-1038.

56. Hely MA, Morris JGL, Reid WGJ, et al. The Sydney multicentre study of Parkinson's disease: a randomized, prospective five year study comparing low dose bromocriptine with low dose levodopacarbidopa. J Neurol Neurosurg Psychiatry 1994; 57: 903-910.

57. Yanagisawa N, Kanazawa I, Goto I, et al. Seven-year follow-up study of bromocriptine therapy for Parkinson's disease. Eur Neurol 1994; 34(Suppl 3): 29-35. 
58. Riopelle RJ, Gawel M, Libman I, et al. A double-blind study of bromocriptine and L-dopa in de novo Parkinson's disease: results of six months. In: Fahn S, Marsden CD, Goldstein M, Calne DB, eds. Recent developments in Parkinson's disease, Vol II. Florham Park: Macmillan Healthcare Information, 1987, 215-219.

59. Olanow CW, Alberts MJ, Stajich J, Burch G. A randomized blinded study of low-dose bromocriptine versus low-dose carbidopa/levodopa in untreated Parkinson's patients. In: Fahn S, Marsden CD, Goldstein M, Calne DB, eds. Recent Developments in Parkinson's Disease, Vol II. Florham Park: Macmillan Healthcare Information, 1987, 201-208.

60. Parkinson's Disease Research Group in the United Kingdom. Comparisons of therapeutic effects of levodopa, levodopa and selegiline, and bromocriptine in patients with early, mild Parkinson's disease: three year interim report. Br Med J 1993; 307: 469-472.

61. Agid Y, Pollak P, Bonnet AM, Signoret JL, Lhermitte F. Bromocriptine associated with a peripheral dopamine blocking agent in treatment of Parkinson's disease. Lancet 1979; 1: 570572.

62. Mear J-Y, Barroche G, de Smet Y, et al. Pergolide in the treatment of Parkinson's disease. Neurology 1984; 34: 983-986.

63. Lieberman A, Goldstein M, Neophytides A, et al. Lisuride in Parkinson's disease: efficacy of lisuride compared with levodopa. Neurology 1981; 31: 961-965.

64. Rinne UK, Bracco F, Chouza C, et al. Cabergoline in the treatment of early Parkinson's disease: results of the first year of treatment in a double-blind comparison of cabergoline and levodopa. Neurology 1997; 48: 363-368.

65. Runge I, Horowski R. Can we differentiate symptomatic and neuroprotective effects in parkinsonism? The dopamine agonist lisuride delays the need for levodopa therapy to a similar extent as reported for deprenyl. J Neural Transm [P-D Sect] 1991; 4: 273-283.

66. Langtry HD, Clissold SP. Pergolide: a review of its pharmacological properties and therapeutic potential in Parkinson's disease. Drugs 1990; 39: 491-506.

67. Ahlskog JE, Muenter MD, Maraganore DM, et al. Fluctuating Parkinson's disease. Treatment with the long-acting dopamine agonist cabergoline. Arch Neurol 1994; 51: 1236-1241.

68. Rinne UK. Combined bromocriptine-levodopa therapy early in Parkinson's disease. Neurology 1985; 35: 1196-1198.

69. Rinne UK. Early combination of bromocriptine and levodopa in the treatment of Parkinson's disease: a 5-year follow-up. Neurology 1987; 37: 826-828.

70. Giménez-Roldán S, Tolosa E, Burguera JA, et al. Early combination of bromocriptine and levodopa in Parkinson's disease: a prospective randomized study of two parallel groups over a total followup period of 44 months including an initial 8-month double-blind stage. Clin Neuropharmacol 1997; 20: 67-76.

71. Przuntek H, Welzel D, Blümner E, et al. Bromocriptine lessens the incidence of mortality in L-Dopa-treated parkinsonian patients: prado-study discontinued. Eur J Clin Pharmacol 1992; 43: 357363.

72. Factor SA, Weiner WJ. Early combination therapy with bromocriptine and levodopa in Parkinson's disease. Mov Disord 1993; 8: 257-262.
73. Rajput AH, Stern W, Laverty WH. Chronic low-dose levodopa therapy in Parkinson's disease: an argument for delaying levodopa therapy. Neurology 1984; 34: 991-996.

74. Poewe WH, Lees AJ, Stern GM. Low-dose L-dopa therapy in Parkinson's disease: a 6-year follow-up study. Neurology 1986; 36: 1528-1530.

75. Lieberman AN, Gopinathan G, Hassouri H, Neophytides A, Goldstein M. Should dopamine agonists be given early or late? A review of nine years experience with bromocriptine. Can J Neurol Sci 1984; 11: 233-237.

76. Grimes JD. Bromocriptine in Parkinson's disease: results obtained with high and low dose therapy. Can J Neurol Sci 1984; 11: 225228.

77. Lieberman AN, Gopinathan G, Neophytides A, Goldstein M. Management of levodopa failures: the use of dopamine agonists. Clin Neuropharmacol 1986; 9: S9-S21.

78. Olanow CW, Fahn S, Muenter M, et al. A multicenter double-blind placebo-controlled trial of pergolide as an adjunct to Sinemet $\AA$ in Parkinson's disease. Mov Disord 1994; 9: 40-47.

79. Ahlskog JE, Muenter MD. Pergolide: long-term use in Parkinson's disease. Mayo Clin Proc 1988; 63: 979-987.

80. Tanner CM, Goetz CG, Glantz RH, Klawans HL. Pergolide mesylate: four years experience in Parkinson's disease. In: Yahr MD, Bergman KJ, eds. Advances in Neurology, Vol 45: Parkinson's Disease. New York: Raven Press, 1986, 547-549.

81. Facca A, Sanchez-Ramos J. High-dose pergolide monotherapy in the treatment of severe levodopa-induced dyskinesias. Mov Disord 1996; 11: 327-341.

82. Factor SA, Sanchez-Ramos JR, Weiner WJ. Parkinson's disease: an open label trial of pergolide in patients failing bromocriptine therapy. J Neurol Neurosurg Psychiatry 1988; 51: 529-533.

83. Goetz CG, Tanner CM, Glantz RH, Klawans HL. Chronic agonist therapy for Parkinson's disease: a 5-year study of bromocriptine and pergolide. Neurology 1985; 35: 749-751.

84. Lieberman AN, Goldstein M. Treatment of advanced Parkinson's disease with dopamine agonists. In: Marsden CD, Fahn S, eds. Movement Disorders, Vol 2. London: Butterworth \& Co (Publishers) Ltd, 1981: 146-165.

85. Parkes JD, Schachter M, Marsden CD, Smith B, Wilson A. Lisuride in parkinsonism. Ann Neurol 1981; 9: 48-52.

86. Lera G, Vaamonde J, Muruzabal J, Obeso JA. Cabergoline: a longacting dopamine agonist in Parkinson's disease. Ann Neurol 1990; 28: 593-594.

87. Felten DL, Felten SY, Fuller RW, et al. Chronic dietary pergolide preserves nigrostriatal neuronal integrity in aged-Fischer-344 rats. Neurobiol Aging 1992; 13: 339-351.

88. Lange KW, Rausch W-D, Gsell W, et al. Neuroprotection by dopamine agonists. J Neural Transm 1994; 43(Suppl): 183-201.

89. Ogawa N, Tanaka K-i, Asanuma M, et al. Bromocriptine protects mice against 6-hydroxydopamine and scavenges hydroxyl free radicals in vitro. Brain Res 1994; 657: 207-213.

90. Lichter D, Kurlan R, Miller C, Shoulson I. Does pergolide slow the progression of Parkinson's disease? A 7-year follow-up study. Neurology 1988; 38(Suppl 1): 122.

91. Zimmerman T, Sage JI. Comparison of combination pergolide and levodopa to levodopa alone after 63 months of treatment. Clin Neuropharmacol 1991; 14: 165-169. 